\title{
Development of an Assessment Scale of Adaptation Difficulty for the Elderly (ASADE) and Its Psychometric Properties
}

\author{
Yaşlılarda Uyum Güçlüğünü Değerlendirme Ölçeği'nin (YUGDÖ) \\ Geliştirilmesi ve Psikometrik Özellikleri
}

\author{
Fatma Nevin ŞİŞMAN ${ }^{1}$, Yasemin KUTLU²
}

\begin{abstract}
SUMMARY
Objectives: The aim of this study was to develop the Assessment Scale of Adaptation Difficulty for the Elderly and determine its reliability and validity.

Methods: The study sample was comprised of 309 elderly participants aged 65 and older living in 2 nursing homes. The theoretical framework for the scale was the Roy Adaptation Model. The construct validity of the scale was tested using exploratory factor analysis, and reliability was assessed using internal consistency and split-half reliability.

Results: The content validity index of the scale was $98.54 \%$. Factor analysis yielded 4 factors with eigenvalues of 1 and above, which explained $65.57 \%$ of the total variance. The alpha coefficient for the scale was 0.93 . Cronbach's alpha values were 0.88 for the first half and 0.89 for the second half; the Guttman Cronbach's alpha value was 0.83 .

Conclusion: The final scale consists of 24 items answered on a 4-point Likert-type scale. The scale is evaluated on the basis of a mean score; the lowest score possible is 0 and the highest is 3 . The closer the individual's score is to 0 , the higher the level of adaptation. The current study found good reliability and validity for the scale. It is recommended for use in determining the extent of adaptation difficulties of the elderly.
\end{abstract}

Keywords: Adaptation; elderly; nursing model; reliability; validity.
ÖZET

Amaç: Bu çalışmanın amacı Yaşlılarda Uyum Güçlüğünü Değerlendirme Ölçeği'nin geliştirilmesi, geçerlik ve güvenirliğinin belirlenmesidir.

Gereç ve Yöntem: Araştırmanın örneklemini iki huzurevinde yaşayan 65 yaş ve üstü 309 yaşlı birey oluşturdu. Ölçeğin kuramsal çerçevesini Roy Adaptasyon Modeli oluşturdu. Ölçeğin yapı geçerliği faktör analizi kullanılarak, güvenilirliği ise iç tutarlık ve yarıya bölme yöntemleri kullanılarak değerlendirildi.

Bulgular: Ölçeğin kapsam geçerliği indeksi \%98.54 olarak bulundu. Faktör analizi sonucunda özdeğeri bir ve üzeri olan toplam varyansın \%65.57'sini açıklayan dört faktör elde edildi. Ölçeğin Cronbach's Alfa değeri 0.93 olarak belirlendi. Yarıya bölme yöntemi sonucunda ise ilk yarının Cronbach's Alfa değeri 0.88; ikinci yarının ise 0.89 olarak belirlendi ve Guttman Cronbach's Alfa değeri 0.83 olarak bulundu.

Sonuç: Tüm analizlerin sonucunda 24 maddeden oluşan dörtlü likert tipi bir ölçek geliştirildi. Ölçeğin değerlendirmesi ortalama puan hesaplanarak belirlenmekte olup, ölçekten alınacak en düşük puan 0 ve en yüksek puan 3'tür. Alınan puan O'a yaklaştıkça uyum seviyesi yükselir. Bu çalışmada ölçeğin iyi bir geçerlik ve güvenirliğe sahip olduğu belirlendi. Ölçeğin yaşlılarda uyum güçlüklerini belirlemek için kullanılması önerilir.

Anabtar sözcükler: Adaptasyon; yașli; hemșirelik modeli; geçerlik; güvenirlik.

\section{Introduction}

Nowadays, the increase in the aging population is a well-documented issue. ${ }^{[1]}$ The World Health Organization (WHO) reports a worldwide population of about 600 million individuals aged 60 and above. It is expected that this figure will increase twofold by 2025, and approach almost two billion by $2050 .{ }^{[2]}$ In Turkey, TurkStat 2014 results show that the elderly population of 65 and over made up $7 \%$ of the total in 2009; this ratio reached $7.7 \%$ in $2013 .{ }^{[3]}$

'Department of Nursing, Marmara University, Faculty of Health Science, istanbul, Turkey

${ }^{2}$ Department of Mental Health and Psychiatric Nursing, İstanbul University Florence Nightingale Nursing Faculty, İstanbul, Turkey

Correspondence (iletişim): Dr. Fatma Nevin şişMAN.

e-mail (e-posta): nevin4083@yahoo.com

Psikiyatri Hemşireliği Dergisi 2016;7(1):25-33

Journal of Psychiatric Nursing 2016;7(1):25-33

Doi: $10.5505 /$ phd.2016.82905

Submitted (Geliş tarihi): 13.03.2015 Accepted (Kabul tarihi): 02.11.2015
WHO emphasizes that subject to this growth in the elderly population, every country should be prepared for the unfavorable consequences, and suggests that in both developed countries and developing countries, health policies should give priority to supporting independent living and community integration for elderly citizens. ${ }^{[2,4]}$

In parallel with this increased growth worldwide, it is expected that the elderly population in our country will become more of an issue sociologically, demographically and economically, especially in the second half of the century.

The natural ageing process is considered to be a consequence of impairment in basic cognitive functions such as attention, perception, memory and thinking, and leads to communication problems within the elderly person's environment. ${ }^{[5]}$ These problems then interfere with his/her adaptation with himself/herself and his/her environment.

Adaptation is an essential process for a happy life in every generation because human life constantly changes. The elderly population is one of the demographic groups that needs 
adaptation, which at this age is considered crucial because of the critical conditions of life in regression, separation, closing of the curtain, and the end of life. Elderly people need to adapt to such events as retirement, becoming a widow/ widower, the death of close friends and relatives, critical illnesses and, eventually, impending death. ${ }^{[6-10]}$

According to Flood, if individuals fail to adapt to physiological and functional changes that emerge as years pass, problematic consequences will arise. If individuals develop coping mechanisms and manage to use them frequently, they acquire a higher level of adaptation than others who can't develop coping mechanisms or use them as often. ${ }^{[11]}$

The number of studies about adaptation to aging in the literature is limited. In one study, the phrase "adaptation to the process of aging" was expressed as a component of wellbeing in the aging process. $81 \%$ of the elderly individuals who participated in the study stated that they adapted to the changes seen in older age, 94\% lived independently in their own house, $38 \%$ don't experience insufficiency, $15 \%$ had no chronic illness and $74 \%$ had active connection with life. ${ }^{[12]}$ The same study reported that as age increases, the state of well-being in the aging process decreases. The state of wellbeing is positively correlated with cognitive sufficiency and level of depressive symptoms is negatively correlated with the perception of stress. ${ }^{[12]}$ Another study observed that many elderly express that state of well-being is only possible with adapting to the process. ${ }^{[13]}$

Roy Adaptation Model (RAM) was developed by Sister Callista Roy, a nursing theorist, in 1964 and implemented in 1968. RAM focuses on human adaptation. According to this model, a person is a system that adapts to the environment by being in constant interaction with a changing environment. [14,15] The nurse helps the person's adaptation by addressing the four needs (physiological needs, self-concept, role function and interdependence). According to Roy, the goal of nursing is the promotion of adaptation in these four modes in sickness and health. The nurse primarily assesses the person's behavior and determines the stimuli that causes this behavior and affects adaptation together with the person. Later, s/he plans, implements and assesses the efficacy of interventions that can be influential on these stimuli. ${ }^{[16]}$ The main goal of the nursing interventions should be enhancing the person's coping mechanisms to be able to fight with stimuli. When the person is capable of coping with the stimuli, the level of adaptation increases and his/her behavior could change from maladaptive to adaptive. ${ }^{[16]}$

Changing maladaptive response to adaptive response should be handled through patient care. Healthcare workers should first determine the level of adaptation that causes problems in the communication of the elderly with him/herself and the environment and provide care accordingly.
When planning the care of elderly, it is important to benefit from diagnostic tools and scales for providing objective data about their condition. There is not measurement tool for diagnosing adaptation problems to ageing process in our country. Existing scales in the literature measure adaptation to either a disease or treatment process afterwards. ${ }^{[17,18]}$ Some scales only measure physiological changes and difficulties or social and psychological adaptation levels. ${ }^{[19-22]}$ It is not possible to measure all these adaptation modes with a single scale. There is no scale that directly measures the level of coping with problems that could be encountered through the ageing process and arising from the process itself and level of adaptation to change. The goal of this study is to develop Assessment Scale of Adaptation Difficulty for the Elderly (ASADE) and to test its psychometric properties. Sub-goals are developing a valid and reliable scale and evaluating the score distributions of participants.

\section{Materials and Method}

\section{Type of Study}

The study was conducted as methodological, descriptive and correlational study in order to develop Assessment Scale of Adaptation Difficulty for the Elderly (ASADE) and to test its psychometric properties.

\section{Setting}

The study was conducted in two Elder Care and Rehabilitation Centers between December 2010 and June 2011. One of the centers, a 645-bed nursing home, dates back to 1895 and is Turkey's oldest and largest institution of its kind. The other center was founded in 2008 and can shelter 136 elderly clients.

\section{Sample}

When calculating the sample size of the study, we used predicted sample size calculation for scale development studies, which is (Number of items):(Observation/number of subjects). Five to 30 observations per item is recommended for this calculation. ${ }^{[23]}$ In this study, we planned at least 10 elderly individuals for each item in the scale and calculated the sample size to be minimum 399 (30x10=300). The study is completed with 309 elderly individuals $(n=309)$. Among individuals living in a nursing home, patients $>65$ years of age, with no visual or auditory disturbances, no psychological disorders and with a Standardized Mini Mental Test score of 24 or higher were included in the study.

\section{Data Collection}

Managers of the Senior Care and Rehabilitation Center were informed about the aim and data collection methods of the study. After obtaining necessary permits, data collecting tools were administered to participants. Each data collecting 
tool information form included a demographic questionnaire that asks about age, sex, education, presence of social security and duration of stay in the nursery along with the final form of the scale. Scale development process took place in three steps.

\section{Step 1: Concept Analysis and Item Creation}

Items should be observable, measurable, and action-oriented and defined considering the theoretical definition the property that is desired to be measured. It is expressed in the literature that when creating scale items, it is possible to form an item pool by analyzing the existing scales on the subject matter. ${ }^{[24]}$ In this study, when creating the scale items, we used (a) studies that investigate physiological, social and cognitive problem areas in ageing, (b) studies that investigate factors that can influence daily life activities in the elderly and affect adaptation to ageing and (c) similar scales about adaptation that were previously used. Theoretical frame of the scale was formed based on Roy's Adaptation Model (RAM), which was developed by Sister Callista Roy, a nursing theorist who states that coping with problems increases the person's adaptation level. ${ }^{[16,25]}$ RAM-based theoretical frame enables all adaptation modes to be measurable with a single measurement tool.

An item pool was prepared covering all four modes of RAM (physiological needs, self-concept, role function and interdependence). A rough draft of the scale was formed with 48 questions picked from the item pool. The questions selected to form sub-themes of the scale were determined to cover all four adaptation modes specified in RAM. There are 13 questions for physiological needs, 16 questions for selfconcept, 8 questions for role function and 11 questions for interdependence in the draft scale. "Katz Index of Independence in Activities of Daily Living" and "Lawton and Brody Instrumental Activities of Daily Living Scale" were used to form the question pool for physiological needs. ${ }^{[22]}$ "Social Adaptation Self-Assessment Scale (SASAS)", "Hacettepe Personality Inventory" and "WHOQOL-100" and "WHOQOL-BREF" scales, which are World Health Organization Quality of Life Older Adults module scales, were used for self-concept, role function and interdependence modes. [19-21] Clarity and comprehensibility of the item expressions in the rough draft were ensured. Responding style for scale items were determined in order to be able to perform measurements. 4-level Likert scale (none, somewhat, quite, very) scoring system, which ensures evaluation for each item that defines the situation desired to measure, was used. The scoring system was valid for each item, with a range of "none" equaling to 0 points and "very" to 3 points.

\section{Step 2: Content Validity Index}

Eight nursing experts were invited to rate the relevance of the 48 items to the definition of "adaptation to ageing". The CVI of the scale was assessed using the Lynn method ${ }^{[26]}$ with regard to relevance, clarity, simplicity and ambiguity, both at the item and scale levels. ${ }^{[27,28]}$ Each item of the scale was rated between 1-4 points in terms of "relevance, clarity, simplicity and ambiguity" by the experts $(1=$ not relevant to the subject, $4=$ very relevant to the subject; $1=$ not clear, $4=$ =very clear; $1=$ not simple, $4=$ very simple; $1=$ ambiguous, $4=$ meaning is clear). The CVI of the scale was found to be $64 \%$, and 18 low rated items were excluded. The remaining 30 items were submitted to expert evaluation once more. Values for relevance, clarity, simplicity and ambiguity of the 30 items assessed at the item and scale levels are shown in Table 1. For the whole scale, the CVI was $98.54 \%$ and its content validity was evaluated as very good.

\section{Step 3: Pilot Testing}

In a pilot study to test egibility and comprehension, 30 elderly people completed the scale, and the Cronbach alpha value was found to be 0.70 . The scale items were not changed after the pilot study.

\section{Data Analysis}

First, descriptive statistics were used to examine the distribution of the scores on each item. Then, Pearson correlation coefficients were calculated to examine the correlations between the items.

The construct validity of the scale was tested using exploratory factor analysis. In this exploratory factor analysis, the maximum likelihood extraction method with a varimax rotation was used to examine the factorial structure of the scale. The number of factors to be extracted was determined

Table 1. Content validity index of ASADE

\begin{tabular}{|c|c|c|c|c|c|c|c|c|}
\hline & \multicolumn{4}{|c|}{ Item level CVI } & \multicolumn{4}{|c|}{ Scale level CVI (\%) } \\
\hline & $n$ & Minimum & Maximum & Mean \pm SD & $\mathrm{n}$ & Minimum & Maximum & Mean \pm SD \\
\hline Relevance & 8 & 3.67 & 4.00 & $3.93 \pm 0.11$ & 8 & 91.60 & 100.0 & $98.42 \pm 2.99$ \\
\hline Clarity & 8 & 3.83 & 4.00 & $3.94 \pm 0.06$ & 8 & 95.83 & 100.0 & $98.63 \pm 1.73$ \\
\hline Simplicity & 8 & 3.83 & 4.00 & $3.93 \pm 0.07$ & 8 & 95.83 & 100.0 & $98.42 \pm 1.82$ \\
\hline Ambiguity & 8 & 3.87 & 4.00 & $3.95 \pm 0.06$ & 8 & 96.60 & 100.0 & $98.72 \pm 1.75$ \\
\hline
\end{tabular}

ASADE: Assessment Scale of Adaptation Difficulty for the Elderly; CVI: Content Validity Index; SD: Standard deviation. 
by checking the initial eigenvalue of each factor. Further, items that loaded on one distinctive factor with a loading greater than 0.45 were retained in the scale. ${ }^{[29]}$ Internal consistency (Cronbach's alphas) and split half reliability (Guttman Cronbach's Alpha) were used to assess the reliability of the scale. ${ }^{[30]}$ Pearson correlation analysis and Kruskal Wallis and Mann Whitney $U$ tests were used to assess the correlations between the scale and participants' individual characteristics, and their significance.

\section{Ethical Considerations}

Study methods were approved by the Yeditepe University Ethical Committee. The purpose and benefits of the research were explained according to the Helsinki Declaration; written and verbal consent were obtained from all participants. Participant anonymity was guaranteed.

\section{Results}

\section{The Characteristics of Participants}

The average age of the participants was $71.25 \pm 6.11$ (min 65 , max 92) and the length of stay in the nursing home was
$6.91 \pm 6.30$ years ( $\min 1, \max 31$ years); it was also noted that $50.5 \%$ of the participants were male, $40.8 \%$ had lost their spouses, $36.9 \%$ were primary school graduates and $64.7 \%$ received social security.

Validity

\section{Construct Validity}

The construct validity of the scale was tested using exploratory factor analysis (for all 30 items). The Kaiser-MeyerOlkin (KMO) measure of sampling adequacy $(\mathrm{KMO}=0.87$, $\mathrm{p}=0.000)$ and Bartlett's test of sphericity $\left(\chi^{2}=5.213, \mathrm{df}=276\right.$, $\mathrm{p}<0.001)$ reached statistical significance, supporting the factorability of the correlation matrix. The first exploratory factor analysis found 7 factors with eigenvalues above 1 that explained up to $70.46 \%$ of the cumulative variance.

At this step when common variance values were studied, two items with a variance value of 0.32 were discarded because they did not disperse into other factors but they formed one factor for a unique question. The factor analysis was conducted again. As a result of this re-analysis, 6 factors explain-

Table 2. Factor structure of the ASADE $(n=309)$

\begin{tabular}{|c|c|c|c|c|}
\hline \multirow[t]{2}{*}{ Items } & Factor 1 & \multirow{2}{*}{$\frac{\text { Factor } 2}{\text { Interdependence mode }}$} & \multirow{2}{*}{$\frac{\text { Factor } 3}{\text { Physiological mode }}$} & \multirow{2}{*}{$\frac{\text { Factor } 4}{\text { Self-concept mode }}$} \\
\hline & Role and self-actualization mode & & & \\
\hline 14 & 0.83 & & & \\
\hline \multicolumn{5}{|l|}{1} \\
\hline & 0.79 & & & \\
\hline 12 & 0.75 & & & \\
\hline 16 & 0.73 & & & \\
\hline 15 & 0.72 & & & \\
\hline \multicolumn{5}{|l|}{24} \\
\hline & 0.71 & & & \\
\hline \multicolumn{5}{|l|}{13} \\
\hline & 0.68 & & & \\
\hline 9 & 0.67 & & & \\
\hline \multicolumn{5}{|l|}{5} \\
\hline & 0.58 & & & \\
\hline 18 & 0.23 & 0.81 & & \\
\hline 17 & 0.19 & 0.80 & & \\
\hline 19 & 0.12 & 0.80 & & \\
\hline 20 & -0.00 & 0.77 & & \\
\hline 22 & 0.17 & 0.71 & & \\
\hline 23 & 0.41 & 0.62 & & \\
\hline 21 & 0.18 & 0.54 & & \\
\hline \multicolumn{5}{|l|}{11} \\
\hline & 0.01 & 0.04 & 0.78 & \\
\hline 10 & 0.15 & 0.07 & 0.74 & \\
\hline 4 & 0.38 & 0.15 & 0.55 & \\
\hline 2 & 0.41 & 0.11 & 0.53 & \\
\hline 7 & 0.11 & -0.01 & 0.23 & 0.87 \\
\hline 8 & 0.18 & 0.11 & 0.19 & 0.80 \\
\hline 6 & 0.30 & 0.39 & 0.28 & 0.50 \\
\hline 3 & 0.40 & 0.30 & 0.33 & 0.46 \\
\hline Eigenvalues & 9.557 & 2.692 & 2.073 & 1.416 \\
\hline Explained variance (\%) & 39.819 & 11.219 & 8.636 & 5.899 \\
\hline Total variance (\%) & 65.57 & & & \\
\hline
\end{tabular}


ing $70.46 \%$ of the total variance emerged. After examining factor distribution, a new analysis was conducted with 4 factors because no content integrity was achieved among the items gathered under one factor. The analysis brought up 4 factors with an eigenvalue of 1 and above and which explained $58.59 \%$ of the total variance. When the results were evaluated, items with common variance values of $0.34,0.41$, $0.42,0.12$ and 0.3 were excluded from the analysis and the factor analysis was conducted again.

In the final analysis, 4 factors explaining $64.85 \%$ of the total variance were obtained. Assessment of the results indicated that one item was loaded on two factors; it was then excluded from the analysis. As a result, 6 items were excluded from the factor analysis and the analyses were completed with 4 factors explaining $65.57 \%$ of the total variance. The results of the factor analysis are presented in Tables 2 and 3. Factors were entitled "Role and self-actualization mode", "Interdependence mode", "Physiological mode" and "Selfconcept mode", respectively; analyses of factors are shown in Table 4.

\section{Reliability}

Reliability was assessed on measures of internal consistency and split half reliability. The alpha coefficient for the scale was 0.70 for the pilot study ( 30 items) and 0.93 for the main study (24 items), indicating a high degree of internal consistency.

In the second step, to assess the reliability of the scale, the split half method was used. The 24 item scale was divided into two: the first 12 items and the last 12 items. The Cronbach's Alpha value of the first half was 0.88 and that of the second one was 0.89 ; the Guttman Cronbach's Alpha value was 0.83 . As a result of the split half method, the reliability of the scale was found to be very good.

As a result of all these analyses, the 4-point Likert-type scale ("None," assigned 0 points, "A little," assigned 1 point, "Very much," assigned 2 points and "A lot," assigned 3 points) was retained for the 24 items. The scale is evaluated on the basis of a mean score; the lowest score possible is 0 and the highest is 3 . The closer the individual's score is to 0 , the higher the level of adaptation. The scale has 4 factors: "Role and self-actualization mode" (items 1, 5, 9, 12, 13, 14, 15, 16, 24), "Interdependence mode" (items 17, 18, 19, 20, 21, 22, 23), "Physiological mode" (items 2, 4,10,11) and "Self-concept mode" (items 3, 6, 7, 8). (Appendix 1).

\section{Associations between Individual Characteristics of the Elderly and the ASADE}

The ASADE mean score of participants in the current

Table 3. Item-total score correlations of ASADE $(n=309)$

\begin{tabular}{lcc}
\hline Items & Item-total correlation & Cronbach's Alpha if item deleted \\
\hline 1 & 0.64 & 0.92 \\
2 & 0.61 & 0.92 \\
3 & 0.67 & 0.92 \\
4 & 0.58 & 0.93 \\
5 & 0.57 & 0.93 \\
& & \\
6 & 0.38 & 0.93 \\
7 & 0.64 & 0.92 \\
8 & 0.40 & 0.93 \\
9 & 0.49 & 0.93 \\
10 & 0.71 & 0.92 \\
11 & 0.46 & 0.93 \\
& & \\
12 & 0.33 & 0.93 \\
13 & 0.68 & 0.92 \\
14 & 0.65 & 0.92 \\
15 & 0.69 & 0.92 \\
16 & 0.70 & 0.92 \\
17 & 0.66 & 0.92 \\
18 & 0.58 & 0.92 \\
19 & 0.59 & 0.92 \\
20 & 0.55 & 0.93 \\
21 & 0.46 & 0.93 \\
22 & 0.55 & 0.93 \\
23 & 0.48 & 0.93 \\
24 & 0.64 & 0.92 \\
\hline Cronbach Alpha for total scale & & 0.93 \\
\hline
\end{tabular}


Table 4. Item-total score correlations of the subscales of ASADE $(n=309)$

\begin{tabular}{|c|c|c|c|}
\hline Factors & Items & Item-total correlation & $\begin{array}{l}\text { Cronbach's alpha if } \\
\text { item deleted }\end{array}$ \\
\hline Factor 1: Role and self-actualization mode & 1 & 0.75 & 0.90 \\
\hline \multirow[t]{8}{*}{ Cronbach's alpha: 0.92} & 5 & 0.55 & 0.92 \\
\hline & 9 & 0.71 & 0.91 \\
\hline & 12 & 0.75 & 0.90 \\
\hline & 13 & 0.67 & 0.91 \\
\hline & 14 & 0.81 & 0.90 \\
\hline & 15 & 0.74 & 0.90 \\
\hline & 16 & 0.71 & 0.91 \\
\hline & 24 & 0.70 & 0.91 \\
\hline Factor 2: Interdependence mode & 17 & 0.76 & 0.84 \\
\hline \multirow[t]{6}{*}{ Cronbach's alpha: 0.87} & 18 & 0.77 & 0.84 \\
\hline & 19 & 0.73 & 0.85 \\
\hline & 20 & 0.68 & 0.85 \\
\hline & 21 & 0.52 & 0.87 \\
\hline & 22 & 0.64 & 0.86 \\
\hline & 23 & 0.55 & 0.87 \\
\hline Factor 3: Physiological mode & 2 & 0.56 & 0.71 \\
\hline \multirow[t]{3}{*}{ Cronbach's alpha: 0.76} & 4 & 0.56 & 0.71 \\
\hline & 10 & 0.64 & 0.67 \\
\hline & 11 & 0.50 & 0.74 \\
\hline Factor 4: Self-concept mode & 3 & 0.54 & 0.80 \\
\hline \multirow[t]{3}{*}{ Cronbach's alpha: 0.81} & 6 & 0.56 & 0.80 \\
\hline & 7 & 0.72 & 0.72 \\
\hline & 8 & 0.71 & 0.72 \\
\hline
\end{tabular}

study was $1.01 \pm 0.57$ (min: 0.04 max: 2.79). Mean scores for individual factors were: Role and self-actualization mode: 1.36 \pm 0.81 (min: 0.00 max: 2.89); Interdependence mode: 0.97 \pm 0.65 (min: 0.00 max: 3.00); Physiological mode: 0.44 \pm 0.54 (min: 0.00 max: 3.00) and Self-concept mode: $0.85 \pm 0.72$ (min: $0.00 \max : 3.00$ ).

When gender, marital status, educational status and social security status were compared to ASADE scores, a significant difference was observed for gender $\left(\chi^{2}=-2.958, \mathrm{p}<0.01\right)$ and educational status $(Z=34.355, \mathrm{p}<0.001)$ but no significant differences were observed for marital status $(Z=1.063, p>0.05)$ and social security status $\left(\chi^{2}=-1.137, p>0.05\right)$ (Table 5).

\section{Discussion}

One major issue of old age is the adaptation impairment of the elderly with respect to themselves and their surroundings, emerging from problems related to the ageing process. Therefore assessing the adaptation levels of the elderly, and consequent planning by health care providers, is critical. There are a few scales that rate the adaptation of individuals in various situations and illness. ${ }^{[31-33]}$ Since the ASADE focuses only on elderly people, it is a helpful and practical scale that can be used by health care professionals responsible for this group.

The fact that the scale is based on an established theory

Table 5. Associations between the individual characteristics and ASADE mean scores $(n=309)$

\begin{tabular}{|c|c|c|c|c|c|c|c|}
\hline Variables & & $n$ & $\%$ & Mean \pm SD & Min.-Max. & $\mathrm{Z} / \chi^{2}$ & $\mathbf{p}$ \\
\hline \multirow[t]{2}{*}{ Gender } & Male & 156 & 50.5 & $1.11 \pm 0.60$ & $0.04-2.79$ & -2.958 & 0.003 \\
\hline & Female & 153 & 49.5 & $0.90 \pm 0.52$ & $0.04-2.29$ & & \\
\hline \multirow[t]{3}{*}{ Marital status } & Single & 99 & 32.0 & $1.00 \pm 0.56$ & $0.04-2.79$ & 1.063 & 0.588 \\
\hline & Widow & 126 & 40.8 & $0.97 \pm 0.56$ & $0.04-0.29$ & & \\
\hline & Divorced & 84 & 27.2 & $1.07 \pm 0.58$ & $0.12-2.79$ & & \\
\hline \multirow[t]{6}{*}{ Educational status } & Illiterate & 46 & 14.9 & $1.40 \pm 0.69$ & $0.12-2.79$ & 34.355 & 0.000 \\
\hline & Literate & 64 & 20.7 & $1.11 \pm 0.50$ & $0.29-2.79$ & & \\
\hline & Elementary school & 114 & 36.9 & $0.95 \pm 0.54$ & $0.04-2.29$ & & \\
\hline & Middle school & 47 & 15.2 & $0.73 \pm 0.40$ & $0.08-1.67$ & & \\
\hline & High school & 25 & 8.1 & $0.94 \pm 0.52$ & $0.17-2.29$ & & \\
\hline & University & 13 & 4.2 & $0.72 \pm 0.50$ & $0.04-1.75$ & & \\
\hline \multirow[t]{2}{*}{ Social security status } & Yes & 200 & 64.7 & $0.99 \pm 0.59$ & $0.04-2.79$ & -1.137 & 0.255 \\
\hline & No & 109 & 35.3 & $1.05 \pm 0.51$ & $0.08-2.21$ & & \\
\hline
\end{tabular}

$\chi^{2}$ : Chi square (Kruskal wallis test); Z: Mann Whitney U. SD: Standard deviation. 
makes it more powerful. Roy is a nursing theorist who addresses the adaptation of the individual; the aim of his theory is to promote an individual's adaptation through four adaptive modes (the physiological mode, the self-concept mode, the role function mode and the interdependence mode) in both healthy and diseased states. ${ }^{[16]}$

Different adaptation modes are assessed with various pre-existing scales intended to measure adaptation levels in the literature. Social Adaptation Self-Assessment Scale can measure social functionality levels. ${ }^{[19]}$ Psychosocial Adjustment to Illness Scale-Self Report aims to evaluate psychosocial adaptation to illnesses. ${ }^{[17]}$ Katz Index of Independence in Activities of Daily Living assesses bathing, dressing, toileting, transferring, continence and feeding activities, which are the activities for providing basic needs required to sustain life. Lawton and Brody Instrumental Activities of Daily Living Scale is designed for independent life in society and assesses ability to use telephone, shopping, food preparation, housekeeping, laundry, mode of transportation, responsibility for own medications and ability to handle finances. ${ }^{[22]}$ WHOQOL-BREF, a World Health Organization Quality of Life Older Adults module scale, is the shorter version of WHOQOL-100 and includes questions about physical health, psychological health, social relationships and environment domains. ${ }^{[21]}$ Hacettepe Personality Inventory includes 8 subdimensions related with personal and social adaptation (self-realization, emotional decisiveness, neurotic tendencies, psychotic symptoms, family affairs, social affairs, social norms and anti-social tendencies). ${ }^{[20]}$ There is no tool that measures all four modes of Roy at once. ASADE saves time because of the small number of questions it contains and provides convenience by measuring all four adaptation modes with one data collection form.

The scale is easy-to-answer because it only includes 24 items. Likert-type scales depend on the person providing information about him/herself and is answerer-centered. ${ }^{[34]}$ Its 4-point Likert type scales provide the opportunity for scoring and obtaining objective data.

The ASADE sub-scales are consistent with Roy's 4 adaptive modes. The scale can be used as a whole, or each factor can be considered individually. The first sub-scale, "Role and self-actualization mode", is critical for assessing the duties of elderly people in the context of their new role arising from the ageing process. The basic need underlying the "Role and self-actualization mode" is social integrity. Inadequacy in this basic role indicates a potential adaptation issue. The second sub-scale, "Interdependence mode", assesses the relationships of elderly people with their supporting systems. Problems experienced in this mode may lead to problems in maintaining emotional integrity. The third sub-scale, "Physiological mode", relates to bodily reactions to stimuli from the environment. This sub-scale provides significant information because it is indicative of problems with bodily behaviors that influence elderly people's adaptation. The last sub-scale, "Self-concept mode", describes the underlying basic need of psychological integrity. Adaptation issues relevant to this field are crucial for assessing the ability to recover and to maintain health.

Psychometric properties of the scale show that it has validity and reliability. The content and the construct validity were established by a panel of nursing experts and by factor analysis. The internal consistency measures were high for all four sub-scales and for the whole scale.

Content validity is the extent to which the items in a scale represent the behavior/characteristic that they will be used to measure both qualitatively and quantitatively. ${ }^{[35]}$ Expert opinions were acquired for the content validity of the scale. Scores obtained from experts are evaluated using Content Validity Index (CVI). One study suggests that CVI value should at least be $83 \%,{ }^{[26]}$ while another suggests a range between 90 to $100 \% .{ }^{[35]}$ In our study, CVI value was $98.54 \%$, which indicates very high content validity.

Construct validity of the scale was evaluated with exploratory factor analysis. Factor analysis is preferred for eliciting components that are supposed to fundamentally explain the cause of formation and naming them when necessary. ${ }^{[36]}$ In our study, exploratory factor analysis resulted in a construct with 4 factor that explains $65.57 \%$ of total variance and a self-value over 1 .

Internal consistency, test-retest (repeatability), parallel forms, split-half and item analysis methods are used to test reliability. ${ }^{[23,35,36]}$ We used internal consistency (Cronbach's alpha coefficient) and split-half methods. Cronbach's alpha calculated for internal consistency of 0.70 or above is considered sufficient for reliability. ${ }^{[35]}$ Cronbach's alpha of our study being 0.93 indicates adequate internal consistency for the scale. Also, item analysis performed during factor analyses revealed correlation values of scale items to be between 0.33 and 0.71. It is reported in the literature that items with total item score correlation lower that 0.20 should not be included in the test. ${ }^{[23,35,36]}$ Our findings are consistent with the literature.

In this study, the adaptation level of elderly people was close to 1 . This result indicates a good adaptation level for those who participated. The average score on the sub-scale "Role and self-actualization mode" was higher than those of the other sub-scales. This result could be interpreted to mean that the alteration of role caused by ageing further impairs elderly people's social integrity.

Increases in ASADE scores with increasing age suggest that impairment in adaptation parallels the ageing process. 
Adaptation scores of the male participants were higher than the women's scores, this difference was statistically significant. Educational status also influences adaptation, and the higher the educational status, the greater the adaptation. Jopp, Rott and Oswald's findings suggest that adaptation of the elderly is affected by age, especially decreasing from old individuals to very old individuals. They also found that being male and being highly educated were each positively related to adaptation to the aging process. ${ }^{[7]}$

\section{Conclusion}

In conclusion, the ASADE is a reliable and valid scale. It has the potential to assist health care providers to assess the adaptation level of elderly people. It is also expected that the development of the Scale will facilitate the empirical investigation of adaptation status in the elderly. Our scale can be used by healthcare providers who work in senior centers or geriatrics clinics to evaluate adaptation levels of the elderly to ageing based on four modes and to determine the direction of nursing practices that is to be planned for elderly with adaptive problems. The scale can also be used by graduate nursing students during their in senior care center, nursing home and house visits as course practice to evaluate adaptation levels of the elderly. Our study included individuals who are 65 years or older and living in a nursing home. New studies with different sample groups can be planned for further testing of the scale.

\section{Limitations}

While the ASADE has been shown to be reliable and valid, the Scale still requires further testing. For instance, the split half method was used to analyze reliability. Test-retest reliability should be calculated to evaluate the stability of the Scale. A cross validation of the Scale with another sample is also required. Finally, further examination of criterion-related validity could further consolidate the scale's credibility.

\section{References}

1. Stark-Wroblewski K, Edelbaum JK, Ryan JJ. Senior citizens use e-mail. Educational Gerontology 2007;33:293-307.

2. World Health Organization. Ageing and life course. Erişim 21.01.2013, http://www.who.int/ageing/primary_health_care/en/index.html.

3. Turkish Statistical Institute (TurkStat). (2014). Elderly statistics 2013. Turkish Statistical Institute, Ankara. Erişim 10.01.2015, http://www.tuik.gov. tr/Kitap.do?metod=KitapDetay\&KT_ID=11\&KITAP_ID=265.

4. Eser S, Saatli G, Eser E, Baydur H, et al. The reliability and validity of the Turkish Version of the World Health Organization Quality of Life InstrumentOlder Adults Module (WHOQOL-Old). [Article in Turkish] Turk Psikiyatri Derg. 2010;21:37-48.

5. Cangöz B, Uluç S. Yaşlılık döneminde meydana gelen psikolojik değişiklikler. İçinde: Gökçe KY, Aslan D, editör. Temel geriatri. Ankara: Güneş Tıp Kitapevleri; 2007. s. 45-53.

6. Ouwehand C, de Ridder DT, Bensing JM. A review of successful aging models: proposing proactive coping as an important additional strategy. Clin Psychol Rev 2007;27(8):873-84.

7. Jopp D, Rott C, Oswald F. Valuation of life in old and very old age: the role of sociodemographic, social, and health resources for positive adaptation. Gerontologist 2008;48:646-58.

8. Jopp $D$, Rott $C$. Adaptation in very old age: exploring the role of resources, beliefs, and attitudes for centenarians' happiness. Psychol Aging 2006;21:266-80.

9. von Faber M, Bootsma-van der Wiel A, van Exel E, Gussekloo J, et al. Successful aging in the oldest old: Who can be characterized as successfully aged? Arch Intern Med 2001;161:2694-700.

10. Gignac MA, Cott C, Badley EM. Adaptation to disability: applying selective optimization with compensation to the behaviors of older adults with osteoarthritis. Psychol Aging 2002;17:520-4.

11. Flood M. A Mid-range nursing theory of successful aging. The Journal of Theory Construction and Testing 2005;9:35-9.

12. Jeste DV, Depp CA, Vahia IV. Successful cognitive and emotional aging. World Psychiatry 2010;9:78-84.

13. von Faber M, Bootsma-van der Wiel A, van Exel E, Gussekloo J, et al. Successful aging in the oldest old: Who can be characterized as successfully aged? Arch Intern Med 2001;161:2694-700.

14. Birol L. Hemşirelik süreci, hemşirelik bakımında sistematik yaklaşım, genişletilmiş 5. baskı. İzmir: Etki Matbaacılık; 2002. s. 75-80.

15. Velioğlu P. Hemşirelikte kavram kuramlar. İstanbul: Alaş Ofset; 1999. s. 372-400.

16. Roy C. The Roy adaptation model. 3rd ed, New Jersey Upper Saddle River: Pearson Prentice Hall Health; 2009. p. 35-50.

17. Adaylar M. Kronik hastalığı olan bireylerin hastalıktaki tutum, adaptasyon, algı ve öz-bakım yönelimleri. İstanbul Üniversitesi Sağlık Bilimleri Enstitüsü Hemşirelik Anabilim Dalı, Doktora tezi, İstanbul 1995.

18. Karadağ A, Göçmen BZ, Korkut H, Çelik B. Ostomili bireylere yönelik uyum ölçeğinin Türkçeye uyarlanması. Ulusal Cerrahi Dergisi 2011;27:206-11.

19. Akkaya C, Sarandöl A, Esen Danaci A, Sivrioğlu EY, et al. Reliability and validity of the Turkish version of the Social Adaptation Self-Evaluation Scale (SASS). [Article in Turkish] Turk Psikiyatri Derg 2008;19:292-9.

20. Özgüven, IE. Hacettepe kişilik envanteri el kitabı. 2. baskı, Ankara: Odak Ofset Matbaacilık; 1992. s. 8-20.

21. Eser S, Saatli G, Eser E, Baydur $\mathrm{H}$, et al. The reliability and validity of the Turkish Version of the World Health Organization Quality of Life InstrumentOlder Adults Module (WHOQOL-Old). [Article in Turkish] Turk Psikiyatri Derg 2010;21:37-48.

22. Diker J, Etiler N, Yıldız M, Şeref B. Association between cognitive status and activities of daily living, life quality and some demographic variables in older than 65. Anadolu Psikiyatri Dergisi 2001;2:79-86.

23. Hatcher L. A Step-by-Step approach to using the SAS System for factor analysis and structural equation modeling. 6th ed. Cary, North Caroline, USA: SAS Institute, Inc. October 2003.

24. Çam MO, Baysan Arabacı L. Tutum ölçeği hazırlamada nitel ve nicel adımlar. Hemşirelikte Araştırma Geliştirme Dergisi 2010;2:59-71.

25. Roy C, Andrews HA. The Roy adaptation model. 2nd ed, Stamford: Appleton and Lange; 1999. p. 30.

26. Lynn MR. Determination and quantification of content validity. Nurs Res 1986;35:382-5.

27. Erefe I. Ölçeklerin niteliği. İçinde: Erefe I, editör. Hemşirelikte araştırma. Istanbul: Odak Ofset; 2002. s. 180-1.

28. Polit DF, Beck CT. The content validity index: are you sure you know what's being reported? Critique and recommendations. Res Nurs Health 2006;29:489-97.

29. Sencan H. Faktör analizi ve güvenirlik. İçinde: Güvenilirlik ve geçerlilik. Ankara: Seçkin Yayıncilık; 2005. s. 355-414.

30. Burns N, Grove S. The practice of nursing research. Apprasial, synthesis, and generation of evidence. St Louis, MO: Saunders- Elsevier; 2009. p. 371-94.

31. Rogers C, Keller C. Roy's adaptation model to promote physical activity among sedentary older adults. Geriatr Nurs 2009;30(2 Suppl):21-6. 
32. Whittemore R, Sister Callista Roy. Adapting to diabetes mellitus: a theory synthesis. Nurs Sci Q 2002;15:311-7.

33. Tsai PF, Tak S, Moore C, Palencia I. Testing a theory of chronic pain. J Adv Nurs 2003;43:158-69.

34. Tezbaşaran AA. Likert tipi ölçek hazırlama kılavuzu, 3. baskı, e-book. 2008. s. 9-51. ISBN: 975-9756-08-5. http://www.academia.edu/1288035/Likert_ Tipi_\%C3\%96l\%C3\%A7ek_Haz\%C4\%B1rlama_K\%C4\%B1lavuzu.

35. Büyüköztürk Ş. Testlerin geçerlilik ve güvenilirliğinde kullanılan bazı ista- tistikler. İçinde: Sosyal bilimler için veri analizi el kitabı, 16. baskı. Ankara: Pegem Akademi; 2012. s. 167-82.

36. Alpar R. Spor, sağlık ve eğitim bilimlerinden örneklerle uygulamalı istatistik ve geçerlik-güvenirlik. Ankara: Detay Yayıncılık; 2010. s. 316-66.

- This study was presented as a poster at the Horatio 2nd European Festival of Psychiatric Nursing (September 20-23, 2012, Stockholm, Sweden).

Appendix 1. Turkish items of Assessment Scale of Adaptation Difficulty for the Elderly (ASADE)*

\begin{tabular}{|c|c|c|c|c|}
\hline & Hiç & Biraz & Oldukça & Çok \\
\hline $\begin{array}{l}\text { 1. Fiziksel olarak günlük aktivitelerinizi (yürümek, yemek yemek, ilaç içmek, } \\
\text { giyinmek, kişisel bakım, uyumak, tuvalet, vb) yapmakta zorlanıyor musu- } \\
\text { nuz? }\end{array}$ & & & & \\
\hline 2. Konuşmakta zorlanıyor musunuz? & & & & \\
\hline 3. Kendinizi ifade etmekte zorlanıyor musunuz? & & & & \\
\hline 4. Bașkalarının söylediklerini anlamakta zorlanıyor musunuz? & & & & \\
\hline $\begin{array}{l}\text { 5. İșitme, görme, tat alma, koklama ve dokunma duyularınızdaki kayıplara } \\
\text { bağlı olarak günlük yașamınızda sorun yaşıyor musunuz? }\end{array}$ & & & & \\
\hline 6. Kendinizi yașam karșısında güçsüz hissediyor musunuz? & & & & \\
\hline 7. Kendinizi üzgün hissediyor musunuz? & & & & \\
\hline 8. Kendinizi sıkıntılı hissediyor musunuz? & & & & \\
\hline 9. Kendinizi fiziksel olarak güçsüz hissediyor musunuz? & & & & \\
\hline 10. Kendi yașamınızla ilgili kararlar vermekte zorlanıyor musunuz? & & & & \\
\hline $\begin{array}{l}\text { 11. Bir gün yașamın sona ereceği düșüncesine bağlı olarak günlük faaliyetleri- } \\
\text { nizi yapmakta sorun yașıyor musunuz? }\end{array}$ & & & & \\
\hline 12. Spor ve egzersiz yapmakta zorlanıyor musunuz? & & & & \\
\hline $\begin{array}{l}\text { 13. Hobilerinizi (el iși, gazete, kitap okumak, vb) gerçekleștirmekte zorlanıyor } \\
\text { musunuz? }\end{array}$ & & & & \\
\hline 14. Alıșveriș yapmakta zorlanıyor musunuz? & & & & \\
\hline 15. Kadın/erkek rolünü yerine getirmekte zorlanıyor musunuz? & & & & \\
\hline 16. Anne/baba rolünü yerine getirmekte zorlanıyor musunuz? & & & & \\
\hline 17. İnsanlar ile sosyal ilișki kurmakta (arkadașlık, dostluk) zorlanıyor musunuz? & & & & \\
\hline 18. İnsanlar sizinle sosyal ilișki kurmakta (arkadașlık, dostluk) zorlanıyor mu? & & & & \\
\hline 19. İnsanlarla olan sorunlarınızı çözmekte zorlanıyor musunuz? & & & & \\
\hline 20. İnsanlar sizinle olan sorunlarını çözmekte zorlanıyor mu? & & & & \\
\hline 21. İnsanları sevmekte sorun yașıyor musunuz? & & & & \\
\hline 22. İnsanlar sizi sevmekte sorun yașıyor mu? & & & & \\
\hline 23. İnsanlar tarafından saygı görme konusunda sorun yașıyor musunuz? & & & & \\
\hline $\begin{array}{l}\text { 24. Duyularınızdaki bozulmalara bağlı olarak insanlarla ilișki kurmakta zorlanı- } \\
\text { yor musunuz? }\end{array}$ & & & & \\
\hline
\end{tabular}

${ }^{*}$ The scale items were given in Turkish language for researchers who want to make cultural adaptation. 